\title{
PARTISIPASI DAN MANAJEMEN LEMBAGA PENDIDIKAN ISLAM OLEH MASYARAKAT PADA YAYASAN ISLAM BAHRUL ULUM BLAWI KARANGBINANGUN LAMONGAN
}

\author{
Muttaqin Choiri, ${ }^{1}$ Ni'matus Sholihah ${ }^{2}$ \\ ${ }^{1}$ Universitas Trunojoyo Madura, Bangkalan ${ }^{2}$ UIN Sunan Ampel Surabaya \\ ${ }^{1}$ muttaqin.choiri@trunojoyo.ac.id, ${ }^{2}$ nickssholihah@yahoo.com
}

\begin{abstract}
This research is basically a study carried out in order to map community participation in the management of Islamic education institutions, in this case as implemented by the Yayasan Islam Bahrul Ulum Blawi Karangbinangun Lamongan, the selection of this location is based on the initial assumption that the institution implements the community plays an active role in the development of Islamic Education institutions. The study in this study relates to: (1) The pattern of community participation in the development of Islamic educational institutions at the Yayasan Islam Bahrul Ulum Blawi Karangbinangun Lamongan? (2) What is the level of success of the model pattern of community participation in the development of Islamic educational institutions at the Yayasan Islam Bahrul Ulum Blawi Karangbinangun Lamongan?

The method used is field research, with qualitative research research that aims to gain an understanding of social reality through inductive thinking processes related to the involvement of researchers in the situations and phenomena under study, the data needed is the field and literature. The data collection method uses Triangulation data with observation, interviews, questionnaires and document studies.

The Result of this reseach, Management developed by the Yayasan Islam Bahrul Ulum is participatory management with an open management system, through several things, including deliberation, joint work, and mutual support between the foundation as the manager, and the community in general as charity investors and jariyah, in this case the community is also a supervisor on the management system of Islamic education institutions.
\end{abstract}

Key Words : Society Participation, Islamic Education Institution

\begin{abstract}
Abstrak
Penelitian ini, dilakukan dalam rangka memetakan partispasi masyarakat dalam pengelolaan lembaga pendidikan Islam, dalam hal ini sebagaimana dilaksanakan oleh Yayasan Islam Bahrul Ulum Blawi Karangbinangun Lamongan, pemilihan lokasi ini didasarkan pada asumsi awal bahwa lembaga ini menerapkan pola partisipasi masyarakat yang menjadikan masyarakat berperan aktif dalam pengembangan lembaga Pendidikan Islam. kajian dalam penelitian ini berkaitan dengan: (1) Pola partisipasi masyarakat pada pengembangan lembaga pendidikan Islam pada Yayasan Islam Bahrul Ulum Blawi Karangbinangun Lamongan ? (2) Bagaimana tingkat keberhasilan model pola partisipasi masyarakat pada pengembangan lembaga pendidikan Islam pada Yayasan Islam bahrul Ulum Blawi Karangbinangun Lamongan ?

Metode yang dipakai penelitian lapangan (field research), dengan pendekatan kualitatif (qualitative research) yang penelitian yang bertujuan untuk memperoleh pemahaman tentang kenyataan sosial melalui proses berfikir induktif dimana ada keterlibatan peneliti dalam situasi dan fenomena yang diteliti Data yang dibutuhkan adalah lapangan dan literatur. Metode pengumpulan datanya menggunakan teknik Triangulasi data dengan observasi, wawancara, kuisioner dan studi dokumen, adapun analisis penelitian yakni dengan membuat catatan lapangan (field recording), membuat catatan penelitian (research recording), mengelompokkan data sejenis (grouping) dan menginterpretasikan data (interpretation).

Hasil penelitian menunjukkan, manajemen yang dikembangkan oleh Yayasan Islam Bahrul Ulum adalah manajemen partisipatif (participation management) dengan sistem pelaksanaan terbuka (open management), melaluli beberapa hal, diantaranya musyawarah, kerja bersama, dan saling dukung antara pihak yayasan sebagai pengelola, dan masyarakat secara umum sebagai penanam saham amal dan jariyah, dalam hal ini masyarakat juga sebagai pengawas pada sistem pengelolaan manajemen lembaga pendidikan Islam.
\end{abstract}

Kata Kunci : Partisipasi Masyarakat, Lembaga Pendidikan Islam 


\section{A. PENDAhuluan}

Pada generasi milenial sebagaimana saat ini, pendidikan bagi sebagian masyarakat meskipun menduduki posisi utama, sebagaimana dalam Angka Partisipasi Kasar pengakses lembaga pendidikan, dari jalur Pendidikan Dasar ke tingkat menengah, pada tahun 2015/2016 menunjukkan angka berkategori tinggi. Dari data menunjukkan, pelajar yang telah lulus tingkat dasar, baik Sekolah Dasar (SD)/ Madrasah Ibtidaiyah (MI) sebesar $329.202(6,76 \%)$ tidak melanjutkan ke tingkat pendidikan yang lebih tinggi dari 4.872.155 yang menamatkan pendidikan dasar. Sedangkan, dari pendidikan menengah Sekolah Menengah Pertama (SMP) atau Madrasah Tsanawiyah (MTs), terdapat jumlah yang cukup tinggi, yang tidak melanjutkan pendidikan ke Sekolah Menengah Atas (SMA) atau Madrasah Aliyah (MA) sebanyak 583.776 $(13,63 \%)$, dari jumlah lulusan 4.283.518 pada tahun pelajaran 2015/ 2016. (Bastari, Sofiah, \& Sudarwati, 2016, p. 20) Kenaikan jumlah lulusan angkatan pendidikan yang tidak melanjutkan pendidikan sekolah ke jenjang yang lebih tinggi, merupakan pekerjaan bersama yang perlu diperbaiki bersama baik oleh pemerintah maupun oleh masyarakat secara umum.

Untuk menjaga keberlangsungan pendidikan Islam, dibutuhkan satu penopang yang harus bekerja secara sinergis yakni keluarga, sekolah, masyarakat dan Negara (Syamsul, 1996, p. 8). Khusus berbicara tentang masyarakat sebagai salah satu penopang kesinambungan pendidikan Islam, maka partisipasi adalah satu hal yang tidak mungkin dipisahkan dari masyarakat dengan kata lain masyarakat harus ikut serta berpartisipasi dalam kesinambungan pendidikan secara umum. Dalam padal 8 dan 9 Undang-undang Sistem Pendidikan Nasional, disebutkan "masyarakat berkewajiban memberikan dukungan sumber daya dalam penyelenggaraan pendidikan dan berhak berperan serta dalam perencanaan, pelaksanaan, pengawasan dan evaluasi program pendidikan".

Yayasan Islam Bahrul Ulum (YIBU) Blawi Karangbinangun Lamongan, merupakan yayasan yang menaungi lembaga pendidikan dari tingkat RA (Raudhatul 'Athfal), MI
(Madrasah Ibtidaiyah), MTs (Madrasah Tsanawiyah), dan MA (Madrasah Aliyah) muncul dan lahir dari persamaan persepsi masyarakat tentang pentingnya akses lembaga pendidikan yang bisa dijadikan sebagai salah satu rujukan lembaga pendidikan Islam alternatif bagi masyarakat. Kehadiran lembaga pendidikan Islam, yang sampai saat ini tetap eksis dalam mengibarkan nilai-nilai luhur pendidikan yang dikelola oleh Yayasan Islam Bahrul Ulum Blawi tidak pernah terlepas dari partisipasi masyarakat, berhimpitan dengan kepungan lembaga pendidikan negeri non keagamaan di sekitar, menjadi tantangan yang setiap waktu memerlukan upaya dan pola program dalam menjaga angka partisipasi pendidikan bagi masyarakat. Partisipasi adalah sebuah sikap yang mencirikan masyarakat dinamis, Conyears, mengidentifikasikan tiga kebutuhan dasar dalam pembangunan masyarakat, salah satu diantaranya adalah partisipasi dalam membuat dan melaksanakan program, selain kebutuhan dasar lainnya seperti pangan sandang dan papan, kemudian pendidikan, kesehatan dan air bersih. (Diana, 1994, p. 45)

Mencermati teori Conyears, antara partisipasi dengan pendidikan keduanya merupakan kebutuhan mendasar dalam pembangunan manusia, sangat dimungkinkan ketika pendidikan membutuhkan partisipasi sehingga menjadi salah satu modal utama dalam meningkatkan kualitas sebuah lembaga pendidikan, maka pola partisipasi dan program baik yang menjadi kerangka acuan sangat perlu dikaji guna mendapatkan pemahaman tentang model-model partisipasi masyarakat sebagai upaya pengembangan lembaga pendidikan Islam. Masyarakat sebagai pemilik kontribusi terhadap kelangsungan penyelenggaraan pendidikan kiranya perlu dikelola secara manajerial agar sumber daya tersebut dapat digali lebih optimal dan memberikan manfaat sebesar-besarnya bagi pembangunan pendidikan sehingga pada saatnya pendidikan akan menjadi milik masyarakat sepenuhnya, pendidikan dari oleh dan untuk masyarakat.

Atas dasar hal tersebut, permasalahan yang akan dikaji adalah sebagai berikut (1) Tentang memahami pola-pola partisipasi masyarakat pada pengembangan manajemen lembaga pendidikan Islam di Yayasan Islam Bahrul Ulum Blawi Karangbinangun 
Lamongan, (2) bagaimana tingkat keberhasilan pada partisipasi masyaralat pada pengembangan lembaga pendidikan Islam di Yayasan Islam Bahrul Ulum Blawi Karangbinangun Lamongan

\section{B. METODOLOGI}

Penelitian tentang Partisipasi dan Manajemen Lembaga Pendidikan Islam oleh Masyarakat pada Yayasan Islam Bahrul Ulum Blawi Karangbinangun Lamongan ini menggunakan pendekatan kualitatif. Pendekatan kualitatif (qualitative research) menurut Schatzman dan Strauss yang dikutip oleh Sugiono, adalah metode penelitian yang bertujuan untuk memperoleh pemahaman tentang kenyataan sosial melalui proses berfikir induktif dimana ada keterlibatan peneliti dalam situasi dan fenomena yang diteliti. (Sugiono, 2006, p. 17) Analisis data secara induktif (Moleong, 2009, p. 10).

1. Lokasi penelitian

Penelitian ini dilaksanakan di Yayasan

Islam Bahrul Ulum, yang berlokasi di desa

Blawi Kecamatan Karangbinangun

Kabupaten Lamongan, pemilihan lokasi ini didasarkan pada kepentingan dan tema penelitian, dikarenakan pada pemenuhan pada hasil studi awal yang dilakukan oleh peneliti.

2. Sumber Data

a) Data tentang konsep manajemen lembaga pendidikan Islam dalam membangun partisipasi masyarakat terhadap pengembangan program Pendidikan Islam.

b) Data tentang kendala-kendala sekolah dalam menggalang partisipasi masyarakat terhadap program Pendidikan Islam

c) Data tentang motivasi masyarakat dalam berpartisipasi terhadap program Pendidikan Islam.

d) Data kesan stakeholder tentang penerapan Manajemen Partisipasi Masyarakat dalam mengembangkan program Pendidikan Islam .

3. Informan Penelitian

Tokoh Masyarakat, Pimpinan dan

Pengurus, Kepala Sekolah dan Fungsionaris, Orang Tua pada Yayasan Islam Bahrul Ulum.

4. Teknik Analisis Data
Untuk membantu dan memudahkan penelitian dalam penelitian, Hamidi menyarankan empat langkah praktis dalam Teknik analisa data, field recording, research recordiing, grouping dan interpretation (Hamidi, 2008, p. 85).

\section{PAPARAN DATA}

Letak Geografis Obyek Penelitian

Yayasan Islam Bahrul Ulum (YIBU) Blawi ini, terletak di Jalan Timur Pasar Blawi Kecamatan Karangbinangun Kabupaten Lamongan Provinsi Jawa Timur, yayasan yang sebelumnya bernama Yayasan Pendidikan Islam Bahrul Ulum (YPIB) Blawi yang sebelumnya berdasar pengesahan Akte Notaris, ini mengawali transformasi dan perubahan nama, sesuai dengan SK Kemenkumham Nomor AHU-0025264.AH.01.04 Tahun 2016, perubahan nama ini, disebabkan dua alasan, pertama lebih didasarkan pada database di Kemenkumham yang sudah menggunakan nama yang sama dengan nama yang terlebih dahulu, dan kedua alasan pengembangan yang direncanakan oleh pimpinan dan pengurus yayasan, agar yayasan ini jauh lebih berkembang, tidak lagi sekedar tentang pendidikan Islam, akan tetapi juga pada spek pengembangan lainnya, bisa ekonomi dan sosial masyarakat di wilayah setempat. (Huda, 2018).

\section{MANAJEMEN PENDIDIKAN ISLAM PADA YAYASAN ISLAM BAHRUL ULUM BLAWI}

Berdasarkan hasil wawancara dengan ketua Yayasan Islam Bahrul Ulum, beliau menyampaikan “.....secara tidak langsung, berdirinya Yayasan Islam Bahrul Ulum ini, bisa dinilai sebagai wacana yang terlambat. Berdiri lembaga-lembaga terlebih dahulu, baru kemudian yayasan ini secara administratif berdiri. Namun lebih jauh dari itu, keinginan yang sedemikian ini muncul dari masyarakat sebagai bagian dari kepedulian terhadap lembaga pendidikan Islam yang ada. Setidaknya butuh proses penjang untuk membudayakan sistem manajemen bisa dijalankan dengan lebih tertata, karena kebanyakan bekerja secara konvensional sebelumnya". (Huda, 2018).

Hampir senada dengan apa yang disampaikan oleh H. Khoirul Anam, sekretaris 
Yayasan Islam Bahrul Ulum Blawi, yang menyatakan : “..kalau manajemen itu dapat diterapkan dengan baik, saya yakin yayasan kita akan maju, tapi selama ini kita kan bekerja secara konvensional atas warisan kepemimpinan dan budaya masyarakat di desa ini, ketika ditanya tentang inovasi dalam pengembangan lembaga pendidikan di yayasan, kembali mengatakan, "saya senang inovasi, dan itu pula yang saya lakukan di kepemimpinan saya pada sekolah di luar yayasan ini, tapi secara substansial beda, karena lembaga yayasan ini, banyak bergantung pada swadaya dan masyarakat sekitar yayasan, selain pelibatan juga, secara tidak langsung, masyarakat sebagai pengawas di sini”. (Anam, 2018)

Dalam pandangannya, H. Khoirul Anam menyebutkan bahwa manajemen membuat pekerjaan menjadi lebih rapi dan terarah, sebagaimana yang disampaikan: "manajemen bisa mempengaruhi pekerjaan kita menjadi lebih rapi dan tertata, tapi pada dasarnya pekerjaan kita dulu sudah rapi walaupun ilmu manajemen baru kita dapatkan kemudian, tapi setidaknya pola manajemen pada kepemimpinan yayasan sudah dilakukan, meski dengan beberapa kelemahan". (Anam, 2018) Begitu pula, H. Mustofa Huda menyampaikan: "Yayasan ini memang harus dikelola dengan prinsip manajemen yang baik, perencanaannnya jelas, target yang ingin dicapai jelas arahnya, sehingga kita kerjanya enak, dan ketahuan mana yang sudah terlaksana dan yang belum, tapi penerapannya belum maksimal, karena keterbatasan baik perseorangan dari pimpinan yayasan, dengan kesibukan pada tugas atau pekerjaan utama sehari-hari, serta kelengkapan sarana prasarana yang dibutuhkan serta perangkat struktur yang bisa berkantor sebagai staf yayasan di luar struktur sebagai tenaga pendidik dan staf di madrasah di bawah naungan Yayasan". (Huda, 2018)

Selama ini kerja-kerja manajemen memang menjadi kebutuhan di sekolah ini, sejauh ini kita mencoba menerapkannya dengan baik, namun memang dapat dikatakan belum berjalan secara maksimal dan berjalan dengan baik. (Huda, 2018)

Dari paparan data di atas diketahui bahwa ada komitmen yang kuat dari yayasan untuk menerapkan prinsip-prinsip manajemen lembaga pendidikan Islam dengan baik, namun memang disadari berbagai pihak belum bisa maksimal dan akan terus diupayakan sebagai perbaikan, pada program-program pengembangan pendidikan, untuk terus diupayakan".

\section{E. ANALISIS}

1. Pola Penerapan Manajemen Pendidikan Islam Di Yayasan Islam Bahrul Ulum Blawi

\section{a. Perencanaan}

Dalam upaya menjaring partisipasi masyarakat atau pemberdayaan masyarakat dalam program yayasan baik program secara umum maupun program pendidikan Islam secara khusus, dalam kepengurusan yayasan saat ini pada dasarnya sudah menerapkan dan menyusun program secara maksimal, baik yang berjangka panjang maupun yang berjangka pendek, dengan mengadakan kegiatan Rapat Kerja yang dilakukan pada tahun 2016 di Pacet Mojokerto dengan menhadirkan semua pengurus Yayasan Islam Bahrul Ulum Blawi dalam pembahasan program-program yang akan dilaksanakan oleh yayasan secara umum, disampaikan oleh $\mathrm{H}$. Mustofa Huda: “.... rapat kerja pengurus yayasan yang pernah dilakukan, untuk mengawali kepengurusan yayasan ini dilakukan sedini mungkin, dengan menggandeng nara sumber pakar pendidikan Islam serta uraian dan paparan penyusunan.

Adanya niat yang semacam ini, setidaknya berkaitan dengan planning dalam pengembangan program manajemen pengelolaan pendidikan, sebagai gambaran bahwasanya Hadits Rasulullah, yang menguraikan tentang niat, sebagai Niat dalam hal ini, bisa dikategorikan sebagai perencanaan yang digunakan sebagai sandaran dan dasar utama sebuah kegiatan, ada banyak ahli yang mengungkapkan, $60 \%$ keberhasilan suatu pekerjaan terletak pada bagaimana sesorang mematangkan dan menyiapkan perencanaan (planning) (Tim Dosen Administrasi Pendidikan UPI, 2008, p. 101) Keterkaitan antara perencanaan inilah, yang dapat dinilai sebagai bagian awal dalam sebuah pekerjaan, yakni dalam rangka memikirkan hal-hal yang terkait dengan usaha dan pekerjaan itu agar mendapatkan hasil maksimal yang 
diharapkan, dan tidak berakhir dengan kesia-siaan (Hafifuddin \& Tanjung, 2003, p. 77).

\section{b. Pengorganisasian}

Secara organisatoris, pengelolaan partisipasi masyarakat adalah tanggung jawab pengurus yayasan, baik pengurus harian atau pengurus inti maupun pengurus bidang humas yakni bidang yang menangani masalah-masalah hubungan yayasan, madrasah dan masyarakt secara umum. Hubungan yang berkaitan secara langsung, dengan partisipasi masyarakat secara lebih luas baik sebagai orang tua murid, donatur maupun warga kehormatan yang berkaitan erat dengan pengembangan lembaga pendidikan di bawah yayasan. Dalam pengorganisasian sistem tata kelola partisipasi masyarakat, yang berkaitan dengan madrasah sebagai lembaga-lembaga pendidikan di bbawah yayasan, secara organisasi sejak kepemimpinan yayasan saat ini, pengelolaannya diserahkan dan dikomando secara langsung oleh pengurus inti yayasan dan dibantu dengan koordinator bidang hubungan masyarakat dan hubungan sosial, serta penggalian dana serta operasional manajemen di bawah koordinasi yayasan Islam Bahrul Ulum Blawi.

Hal ini, sejalan dengan prinsip manajemen yakni Pembagian tugas dan wewenang sebagai prinsip pengorganisasian dalam Islam. Wewenang bisa dimaknai kekuasaan untuk mengambil keputusan atau kebijakan yang bersifat mengikat dan harus dijalankan oleh bawahan dan mentaati keputusan tersebut. (Sinn, 2006, p. 94). Wewenang semakin besar jika kedudukan seorang dalam organisasi semakin tinggi. Ketinggian kedudukan dan kebesaran wewenang pada diri seseorang hendaklah disertai keinginan yang kuat untuk menjalankannya berdasarkan ketentuan, hal ini kemudian disebut dengan amanah (Hafifuddin \& Tanjung, 2003, p. 102). Pemimpin yang menjalankan kewenangannya dengan penuh amanah adalh prinsip kepemimpinan dalam organisasi Islam.

\section{c. Pelaksanaan}

Untuk mendapatkan gambaran tentang realisasi dan implementasi partisipasi masyarakat. Kondisi umum yang terjadi di lapangan menunjukkan ada implementasi partisipasi masyarakat dalam program lembaga pendidikan di yayasan. Berikut gambaran partisipasi masyarakat pada beberapa kepemimpinan dan masa yang ada pada Yayasan Islam Bahrul Ulum Blawi;

\section{1) Pola Partisipasi Mandiri}

Pada awalnya berdirnya lembaga pendidikan Bahrul Ulum Blawi, sejak awal berdasar pada partisipasi masyarakat secara umum. Pada tahun-tahun awal berdirinya, belum ada biaya operasional dan bantuan pemerintah ke madrasahmadrasah. Sehingga semua kegiatan pembangunan dan lain-lain, lebih banyak lahir dari masyarakat secara umum sebagai penggerak berdirinya madrasah di desa Blawi. (Malikan, 2018)

Sumbangan dan bantuan, serta tanah wakaf tempat berdirinya madrasah lahir dari partisipasi masyarakat, selain dana serta tanah, partisipasi masyarakat juga berkaitan dengan partisipasi di berbagai bidang, diantaranya tenaga dan juga fikiran, sebagai bentuk partispasi masyarakat secara umum (Malikan, 2018). Hal ini, berlangsung sejak awal berdirinya sekolah, sampai benar-benar terwujud berdirinya Yayasan Pendidikan Islam Bahrul Ulum (YPIB) Blawi di tahun 1990. Sebagai lembaga tempat bernaung lembaga pendidikan (madrasah) di Blawi Karangbinangun Lamongan.

\section{2) Pola Partisipasi Terbatas}

Sejak era berdirinya Yayasan Pendidikan Islam Bahrul Ulum (YPIB) Blawi, berdirinya yayasan ini secara tidak langsung diupayakan untuk mengakomodir kepentingan lembaga di bawahnya. Pengelolaan yayasan, termasuk pola partisipasi masyarakat di bawah YPIB masih didominasi pada partisipasi terbatas, hal ini bisa dicontohkan karena pengurusan yayasan masih berkaitan erat dengan pengurusan di madrasah. Pengurus yayasan, sekaligus pengurus dari pihak manajemen sekolah/ madrasah. 
Dalam partisipasi masyarakat ini, sebagaimana contoh "ketika terlihat gedung madrasah mulau mengalami kerusakan serta seringkali terendam banjir karena karakter wilayah desa Blawi sebagai daerah Bonorowo. Masyarakat berduyun-duyun, menghendaki pembangunan gedung baru dengan banyak memberikan sumbangan, baik materil maupun immateril. Ada yang berbentuk pasir, semen, uang dan juga tenaga". (Malikan, 2018)

\section{3) Pola Partisipasi Mobilisasi}

Sejak tahun 2016, setelah keluar ijin Yayasan Islam Bahrul Ulum (YIBU) Blawi Karangbinangun Lamongan, dengan kepengurusan sebagaimana diurakaian sebelumnya, manajemen Yayasan secara langsung berusaha untuk melakukan modernisasi pola partisipasi masyarakat dalam pengembangan lembaga pendidikan Islam.

Dalam kebijakan pola partisipasi terstruktur ini, Yayasan yang saat ini digawangi putra-putri terbaik dari desa Blawi sendiri, mereka yang telah berkiprah sedemikian luas di masyarkat secara umum, didapuk sebagai pengurus inti/ pengurus harian di Yayasan Islam Bahrul Ulum Blawi. Menurut H. Agus Salim, "upaya untuk menjadikan putraputri terbaik baik duduk di pimpinan yayasan ini, sebagai upaya yayasan agar beliau-beliau yang sudah berkiprah di luar lembaga di Blawi sendiri, bisa mengabdi dan berpartisipasi secara nyata". (Salim, 2018)

Dalam teori partispasi, strategi konsep partisipasi dapat memberikan lebih kemanfaatan, diantaranya (Muhadli, 2009, p. 9),

a. Mampu merangsang timbulnya swadaya masyarakat yang merupakan dukungan penting bagi pengembangan lembaga

Hal ini sebagaimana diungkapkan bendahara Yayasan, sejak mulai penerapan prinsip-prinsip dalam manajemen pengeloaan lembaga pendidikan Islam, baik secara kualitatif maupun kuantitatif sumbangan dan partisipasi meningkat. b. Mampu meningkatkan motivasi dan ketrampilan masyarakat dalam pengembangan lembaga

Sebagai bagian yang tidak terpisahkan dalam pola partisipasi masyarakat, dalam pengembangan Islam. Di Yayasan Islam Bahrul Ulum Blawi, pada pengelolaan manajemen yayasan, dikembangkan unsur-unsur partisipasi aktif, dimana pengurus yayasan yang juga sebagai masyarakat turut aktif dalam mengembangkan yayasan pendidikan. Diantaranya, adalah kegiatan bazar amal, dalam bazar amal ini, biasanya harga jual barang dijual lebih dari 50\% dari harga beli di pasaran. Misalnya, di pasar harga nasi bebek dijual 15.000, di arena bazar amal yang digagas masyarakat bisa dijual seharga 20.000 - 25.000, dan hal ini sudah menjadi jamak serta mafhum bagi masyarakat karena keuntungan kegiatan semacam ini digunakan sebagai amal bagi pengembangan yayasan Islam Bahrul Ulum Blawi.

c. Pelaksanaan pembangunan makin sesuai dengan aspirasi dan kebutuhan masyarakat

Sebagai salah satu yayasan pendidikan Islam yang dikembangkan dari dan untuk masyarakat, Yayasan Islam Bahrul Ulum Blawi juga mengedepankan nilai-nilai pembangunan yang pro kemasyarakatan, diantaranya pembangunan akses jalan, baik untuk ke madrasah maupun dari madrasah untuk masyarakat.

Pada tahun 2017 ini, Yayasan Islam Bahrul Ulum Blawi, telah selesai menyelesaikan proses wakaf tanag oleh masyarakat, yang diwakafkan untuk pengembangan madrasah. Dikarenakan kebutuhan, madrasah dan juga masyarakat sekitar dalam akses keamananan dan percepatan laju ekonomi, yayasan atas inisiatif bersama melakukan pembangunan jembatan penghubung yang bisa diakses masyarakat (Salim, 2018).

d. Tidak menciptakan ketergantungan masyarakat terhadap pemerintah 
Bagi Yayasan Islam Bahrul Ulum Blawi, sebagai lembaga yang berdiri atas swadaya masyarakat, saat ini tengah berjuang dalam rangka untuk penguatan ekonomi lembaga, sehingga beberapa aspek modal, dan juga aspek bisnis dalam pengeloaan Yayasan, bisa diandalkan sebagai salah satu penopang modal dalam pendidikan. Dengan tidak menggantungkan pada sumbangan pada pemerintah, Yayasan Islam Bahrul Ulum, diharapkan ke depan memiliki daya tawar yang kuat baik secara kelembagaan maupun secara tata kelola manajemen keuangan lembaga. Sebagaimana disebutkan, ada beberapa kegiatan yang saat ini digagas, diantaranya; pendirian YIBU mart, BMT YIBU, YIBU Travel, UD. YIBU TANI, serta beberapa program pendampingan yang dilakukan atas kerjasama dengan pemerintahan desa, sebagai upaya penguatan manajemen ekonomi bagi YIBU.

Masyarakat di sisi lain merupakan kelompok manusia yang saling terkait oleh sistem, adat istiadat dan hukum yang berlaku (Mubarok, 2006, p. 5). Dalam pengertian yang hampir sama disebutkan bahwa masyarakat sebagai sekumpulan orang yang hidup di suatu wilayah yang memiliki aturan atau norma yang mengatur hubungan satu sama lain, pola hubungan antar individu dalam masyarakat tersebut pada dasarnya memiliki nilai-nilai yang diakui bersama dan diabadikan dalam norma dan aturan yang umumnya tidak diverbalkan.

Dalam konteks sekolah atau madrasah, masyarkat adalah warga atau individu yang berada di sekolah atau madrasah dan di sekitar madrasah yang berhubungan secara langsung atau tidak langsung terhadap lembaga. Masyarakat pendidikn adalah segenap komponen terkait yang memiliki hak serta kewajiban yang sama dalam merencanakan, melaksanakan dan mengawasi program pendidikan, sehingga lazim muncul pernyataan tentang stake holder atau pihak yang berkepentingan untuk melakukan tugas-tugas tersebut. (Pidarta, 1997, p. 72).

Sebagaimana kita ketahui bahwa pengawasan dan evaluasi adalah bagian yang ikut menentukan sukses tidaknya sebuah program, bahkan evaluasi adalah saving information yang akan dijadikan rujukan bagi pengambilan kebijakan berikutnya. Pengawasan dan evaluasi ini bertujuan untuk memastikan bahwa SDM yang ditugaskan memiliki tanggungjawab atau tidak terhadap tugas yang dibebankan kepadanya, apakah ia telah menunjukkan kinerja baik sehingga target organisasi dapat terwujud sesuai rencana atau tidak dan sebagainya.

Dalam pengamatan peneliti, fungsi manajemen yang satu ini sangat minim. Apa yang telah dilakukan berkaitan dengan program partisipasi berakhir begitu saja tanpa ada saving informasi yang dapat dijadikan bahan kajian untuk pengambilan keputusan berikutnya. Sehingga tidak nampak adan peningkatan kinerja dari waktu ke waktu.

Berdasarkan hasil pengamatan, dalam penelitian dan observasi yang dilakukan, terdapat beberapa faktor yangikut mempengaruji motivasi berpartisipasi masyarakat dalam penyelenggaraan pendidikan, yakni :

(a) Manajemen Yayasan

Upaya menjadikan tokoh tertentu, serta putra-putri terbaik sebagai salah satu strategi manajerial yang cukup jitu. Meskipun terkadang jarak serta waktu dan kesibukan masing-masing pimpinan yayasan sedikit terkadang menjadi penghambat, namun strategi komunikasi yang dibangun dengan memanfaatkan perkembangan teknologi, jaringan internet, dan lain-lain sedikit teratasi.

Pola manajemen yayasan, yang mengedepankan profesionalitas terbuka, dan bersifat kolektif kolegial sebagaimana diterapkan saat ini, menjadi salah satu daya tarik tersendiri dalam pengelolaan lembaga manajemen pendidikan Islam.

(b) Partisipasi Lembaga Pemerintahan Desa

Pribadi dan latar belakang seseorang pemimpin sangat mempengaruhi sikap dan motivasi kerja orang yang dipimpin, sehingga akan berpengaruh pula pada relasi sebuah kebjakan.

Disamping beberapa faktor yang mempengaruhi partisipasi lainnya, telah terjadi sesuatu yang berbeda ketika seorang pimpinan desa yang juga berpredikat da'i atau muballigh. 
Bagaimana dengan kepemimpinan kepala desa tempat bernaungnya lembaga pendidikan Islam, cukup memiliki peran yang sangat penting, selain secara personal dilaksanakan sendiri, juga hal ini memberikan efek ke perangkat dan struktur pemerintahan desa lainnya. Bagaiman pihak desa, selain memberikan sumbangsih materil dengan dibangunnya infastruktur pendukung, juga mengupayakan perolehan dana dari jaring aspirasi masyarakat melalui anggota legislatif yang ikut berperan serta dalam pengembanagn lembaga pendidikan Islam.

Dikatakan oleh H. Khoirul Huda, selaku kepala desa; "seringkali jika mengandalkan dan berupaya keras untuk menarik sumbangan dari warga, ataupun dari wali siswa, perolehan dana pembangunan seperti pavingisasi, rencana pembangunan jembatan penghubung antar unit pendidikan di bawah yayasan mengalami kendala, pihak pemerintahan desa mengupayakan melalaui dana-dana aspirasi masyarakat, bisa melalui anggota legislatif maupun dana bantuan sosial, baik dari pemerintah daerah, maupun provinsi" (Anam, 2018).

(c) Akuntabilitas Publik

Seiring perkembangan masa, dan peningkatan kemampuan baik secara akademik maupun pengetahuan, hal ini mendorong beberapa pihak biasa bersikap kritis dan vokal akan halnya, kebijakankebijaka tertentu. Baik di tingkat paling kecil misalnya, RT, Desa dan lain sebagainya.

Yayasan Islam Bahrul Ulum Blawi, sebagai lembaga yang sejak awal dari partispasi masyarakat yang menginginkan kemajuan pendidikan di desa Blawi, kepemimpinan yayasan pun, dalam berbagai hal dituntut untuk berlaku secara transparan serta akuntabel.

Dalam upaya ini, pimpinan yayasan berusaha menerapkan kepemimpinan secara kolektif kolegial. Hal ini digunakan, sebagai upaya menghilangkan kesan tertutup dalam persoalan transparansi keuangan. Selain hal tersebut, setiap hasil donasi, neraca keuangan yayasan dilakukan penyampaian baik dalam forum resmi rapat yayasan maupun rapat pimpinan tentang kondisi keuangan.

Menurut H. Mustofa, "meskipun masing-masing pengurus inti berdomisili berbeda dan berjauhan, bahkan lintas kabupaten / kota, bendahara yayasan dalam pengelolaan anggaran berusaha melakukan koordinasi serta persetujuan dari ketiga pimpinan inti tersebut. ini yang menjadi alasan, kenapa tidak ditunjuknya wakil dari masing-masing pengurus yayasan tersebut, agar koordinasi bisa langsung diimplementasikan melalui pengurus inti yayasan yang bertanggungjawab" (Huda, 2018).

\section{KESIMPULAN}

Berdasarkan hasil penelitian, pengamatan dan pengkajian bahwa ma.najemen pelaksanaan partisipasi masyarakat dalam pengembangan pola partisipasi manajemen pendidikan Islam pada Yayasan Islam Bahrul Ulum, dapat diuraikan dan disimpulkan sebagai berikut :

1. Manajemen yang dikembangkan oleh Yayasan Islam Bahrul Ulum adalah manajemen partisipatif (participation management) dengan sistem pelaksanaan terbuka (open management), melaluli beberapa hal, diantaranya musyawarah, kerja bersama, dan saling dukung antara pihak yayasan sebagai pengelola, dan masyarakat secara umum sebagai penanam saham amal dan jariyah, dalam hal ini masyarakat juga sebagai pengawas pada sistem pengelolaan manajemen lembaga pendidikan Islam.

2. Dengan pelibatan partisipasi masyarakat model tersebut, masyarakat secara tidak langsung merasa ikut memiliki dan turut andil dalam pengembangan program pendidikan Islam, sehingga manajemen sekolah atau yayasan merasa memiliki tanggung jawab kepada masyarakat, baik dalam materi maupun non materi.

\section{DAFTAR PUSTAKA}

Anam, K. (den 20 Agustus 2018).

Sekretaris Yayasan. (M. Choiri, Intervjuare) 
Bastari, Sofiah, S., \& Sudarwati. (2016). Indonesia Educational Statistics In Brief 2015/ 2016. Jakarta:

Kementerian Pendidikan dan Kebudayaan.

Diana, C. (1994). Perencanaan Sosial di Dunia Ketiga . Yogyakarta: Gajah Mada University Press.

Hafifuddin, D., \& Tanjung, H. (2003). Manajemen Syariat dalam Praktek. Jakarta: Gema Insani Press.

Hamidi. (2008). Penelitian Kualitatif

Pendekatan Praktis Penulisan

Proposal Dan Penelitian. Malang:

Universitas Muhammadiyah

Malang.

Huda, M. (den 15 Agustus 2018).

Wawancara Lembaga / Yayasan.

(M. Choiri, Intervjuare)

Malikan, H. M. (den 22 Agustus 2018).

Perintis Madrasah dan Yayasan

Islam Bahrul Ulum . (M. Choiri, Intervjuare)

Moleong. (2009). Metode Penelitian

Kualitatif. Bandung: Remaja

Rosdakarya.

Mubarok, Z. (2006). Sosiologi Agama;

Tafsir Sosial Fenomena Multi

Religious Kentemporer. Malang:

UIN Press.

Muhadli, Z. (2009). Pembangunan Berbasis

Rukun Tetangga (PBRT) dalam

Perspektif Perubahan Sosial

Budaya pada Masyarakat

Kabupaten Sumbawa Barat :

Sebuah Kajian Fenomenologis.

Malang: Pascasarjana UNMER.

Pidarta, M. (1997). Landasan

Kependidikan. Jakarta: Rineka

Cipta.

Salim, H. A. (den 22 Agustus 2018).

Bendahara Yayasan Islam Bahrul

Ulum . (M. Choiri, Intervjuare)
Sinn, A. I. (2006). Manajemen Syari'ah; Sebuah Kajian Historis dan Kontemporer. jakarta: PT. Raja Grafindo Persada.

Sugiono. (2006). Metode Penelitian Kuantitatif, Kualitatif dan RnD. Bandung: Alfabeta.

Syamsul, A. (1996). Spiritualitasi Islam dan Peradaban Masa Depan. Yogyakarta: Si Press.

Tim Dosen Administrasi Pendidikan UPI. (2008). Manajemen Pendidikan . Bandung: Alfabeta. 